М.Л. Зайцева

\title{
ДУХОВНЫЕ ОЩУЩЕНИЯ КАК ОСНОВА ЭСТЕТИЧЕСКОГО СОЗНАНИЯ ЭПОХИ СРЕДНЕВЕКОВЬЯ
}

\begin{abstract}
Аннотация. Предмет исследования - синестезийность как системное свойство мышления. Автором предпринята попытка доказать, что эстетическая выразительность художественного образа в эпоху Средневековья определялась способностью всех элементов сакрального искусства выступать в роли импульсов для сенсорных ощущений и возникающего эмоционального резонанса. Выявлено, что синестезийное восприятие соборных искусств предполагает наличие синергического эфрфекта, производимого литургическим образом, понимаемым как символ, сакральный носитель божественной энергии и духовной силы прообраза, сакрально-онтологический феномен, реально являющий членам богослужения духовный архетип. Методологической основой статьи является общенаучный метод обобщений и сравнений (для обоснования интегративного характера синестезии как проявления принципа холизма) и конкретно исторический метод, позволяющий выявить основные мировоззренческие факторы, оказавшие влияние на развитие искусства эпохи Средневековья. Статья посвящена анализу синестезийных основ художественного мышления эпохи Средневековья. В ней впервые рассматривается искусство с позиции синестезийности как системного свойства художественного мышления и эстетического восприятия. Обосновано, что эстетическое восприятие соборных искусств обусловливалось именно тем, что искусство и богословие были взаимокоррелирующими полюсами, создающими облик культуры как духовно-энергетического поля. Выявлена важность интероцептивных ощущений в прочессе художественно-эстетического восприятия.

Ключевые слова: синестезия, синестезийность художественного мышления, духовные ощущения, духовное зрение, духовное видение, психология творчества, богословие, искусство эпохи Средневековья, соборные искусства, эстетическое восприятие.
\end{abstract}

«Он пришел верующих в Него соделать новым умом, новою душою, новыми очами, новым слухом, одним словом сказать, новыми людьми... Ибо говорит, что новое вино должно

вливать в новые мехи» ${ }^{1}$.

Искусство эпохи европейского Средневековья предлагает нам особые познавательные модели, то увлекая в мир неизрекаемых истин, то раскрывая красоту бытия через гармонию живописных линий. Каков вклад этих культур в развитие теорий эстети-

\footnotetext{
1 Макарий Великий. Иносказательное изъяснение видения, описанного Пророком Иезекиилем / Преподобный Макарий Великий. Беседы // Добротолюбие (в русск. пер.). Изд-е второе, доп. Т. 14. Киев: PSYLIB, 2006. (psylib.org.ua/ books/dobrl05/).
}

ческого восприятия и художественного мышления, каким образом воплощается в них идея целостного, основанного на синестезийности, сознания? Понимание глубинных основ художественного творчества и его восприятия позволит глубже понять смысл искусства ушедших эпох, увидеть в них горение исследовательского духа и оценить результаты творческих поисков деятелей Средневековья. Этот опыт позволит яснее увидеть проблемы дня сегодняшнего и, возможно, найти на них свое решение.

Синестезийность, или взаимосвязь ощущений, есть условие адекватности субъекта жизни самой жизни. Единство бытия связано с холистическим, целостным характером сознания ${ }^{2}$. Множество

Гуревич П.С. Проблема целостности человека. М.: ИФ РАН, 2004. С. 175. 


\section{Многообразие религиозного опыта}

исследований, посвященных синестезии, свидетельствуют о стремлении ученых к освоению тем, находящихся на стыке различных областей гуманитарного знания. Это, безусловно, способствует интеграции научных знаний и развитию науки в целом. Вместе с тем, исследования синестезийных основ художественного мышления свидетельствуют об общем состоянии современной науки, до сих пор не в полной мере использующей безграничный опыт богословия. Глубина разработки в богословской литературе сложных вопросов, связанных с процессами самопознания и творчества, вдохновляет и существенно дополняет накопленные в различных предметных областях знания и проливает свет на те духовные скрепы, которые направляют сознание (в том числе и художественное) к незримому, неизреченному, к чистоте души, открытой Богу и ищущей Его, к свету преображения.

Реальность существования наряду с ощущениями тела особых духовных ощущений не вызывает сомнений и с очевидностью доказывается практикой: ведь если бы совсем не было у человека духовных ощущений веры, совести, правды, то немыслимыми были бы в мире детекторы лжи. 0 сокровенных рецепторах (внутреннем слухе и зрении) и их болезнях писали еще древние авторы. В частности, о духовном насморке как результате «потери добродетели, коею ощущалось благоухание Христово» рассуждал преп. Евагрий ${ }^{3}$.

Как соотносится это внутреннее видение, слышание с более изученными способами восприятия при помощи внешних органов чувств? Августин, Ареопагит, Бонавентура, Гуго Сен-Викторский, Фома Аквинский отмечали, что видимое глазами ни в коем случае не сравнимо с тем, что усматривает ум, «только разумное зрение не обманывает», телесное же зрение «принимает подобие за самые тела» 4 .

Внутреннее чувствование предполагает осознанность впечатлений, вызванных внешними факторами, особую культуру восприятия. Ее ориентиром является понятие, вновь апеллирующее к внутренним ощущениям - трезвенность ума. Для этого необходима культура восприятия, ориентирующаяся на аскетическую установку содер-

\footnotetext{
Евагрий Понтийский. 33 главы аналогий, или уподоблений. (simvol-veri.ru/.../evagriie-pontiieskiie.-evagriya-monaxanastavleniya-o...).

4 История эстетики. Памятники мировой эстетической мысли: В 5-и тт. Т. 1: Античность, Средние века, Возрождение. М. : Изд-во Академии Художеств СССР, 1962. С. 387.
}

жания ума в чистоте. Умаление этой чистоты ума, совершающееся под воздействием «опьяняющих» чувственных страстей, приводит к искажениям восприятия человеком мира, социума, самого себя. Синестезийное восприятие, подчиняющееся регламентации с помощью аскетической практики духовного трезвения, становится важным этапом достижения сверхчувственного познания Божественных энергий ${ }^{5}$.

Творческое вдохновение в античной философии понималось как мания ( $\mu \alpha v i ́ \alpha$, в пер. с греч. -

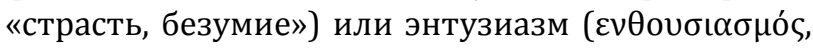
в пер. с греч. - «божественное вдохновение, восторг»). Согласно учению Платона безумие и неистовство могут быть и заболеванием, и действием в человеке богов - таковы прорицания, поэтическое неистовство (как одержимость Музами), безумство любви. В «Ионе» Платон определяет поэта как существо «легкое, крылатое и священное», способное творить лишь тогда, когда «сделается вдохновенным и исступленным и не будет в нем более рассудка» ${ }^{6}$.

Если Платон употребляет понятие одержимости каким-либо из богов для характеристики творческого вдохновения, в результате которого поэт приобщается к тайнам бытия, то для средневековья «одержать» человека могут лишь духи тьмы, бесы. Чтобы не наполнилась душа «великим зловонием» и «не возгнездились в ней пресмыкающиеся - лукавые духи», человек, по мнению христианских аскетов, должен отдаваться высшему началу не безрассудно, но в состоянии высшей духовной трезвенности, в бодрственном внимании сердца, различающего добро и зло7. Критерием в данном случае служили действия благодати на душу человека, научающие ее смирению, кротости, сочувствию, отсечению похотей, т.е. тем душевным добродетелям, которые невозможно обрести при

\footnotetext{
Медушевский В.В. Куда идем - куда заворачиваем? // Музыка изменяющейся России: Материалы всероссийской научно-практической конференции / Гл. ред. М.Л. Космовская. Отв. ред. В.А. Лаптева и Л.А. Ходыревская. Курск : Изд-во Курск. гос. ун-та, 2007. С. 23.

6 Платон. Собр. соч. в 4-х тт. / Пер. с древнегреч.; Под общ. ред. А.Ф. Лосева, В.Ф. Асмуса, А.А. Тахо-Годи. Т. 2. М.: Мысль, 1993. С. 216.

Макарий Великий. Иносказательное изъяснение видения, описанного Пророком Иезекиилем / Преподобный Макарий Великий. Беседы // Добротолюбие (в русск. пер.). Изд-е второе, доп. Т. 14. Киев: PSYLIB, 2006. С. 223. (psylib. org.ua/books/dobrl05/).
} 
помощи бесовских сил. Когда же душа, отчистившись от страстей, соделавшись неукоризненной, сорастворяется со Святым Духом, то, по словам Макария, «делается она вся светом, вся оком... нет у нее ни одной части, не исполненной духовных очей света, ... и возвращается ей ее естественная прозорливость» ${ }^{8}$. Опасно для человека не только ложное одухотворение, но и простое отпускание чувств и «скитание помыслов», что хуже, чем стрелять из лука наугад. Поэтому испытание помыслов - закон внутренней жизни человека.

Отметим, что средневековая эстетика, интериоризируя свои понятия, соединяя их с этикой и психологией, создает специфическое понимание удовольствия, которое греховно не только потому, что представляет собой разжигание, форсирование чувств, но и потому, что является следствием онтологического обмана, подменяющего истину заблуждением ${ }^{9}$.

В средневековой богословской культуре звуковые, визуальные, вкусовые, тактильные, обонятельные ощущения мыслились как целостная, но индивидуально выстроенная система восприятия, способствующая отражать божественный свет и направлять к духовному преображению. Символизм мышления предполагал наличие определенного вектора понимания смысла сакральных символов, направленного к Божественному Прообразу, и наличие свободной, обусловленной индивидуальными особенностями человека вариации смыслов. Светоносному образу Бога соответствует понимание восприятия как светового по своей природе. Об этом писал Бонавентура, полагая, что световую природу чувствительности «видно по нервам, имеющим природу ясную и светопроводящую. В пяти чувствах свет различается в зависимости от большей или меньшей чистоты» ${ }^{10}$.

Главенствующая роль Логоса в комплексе соборных искусств определяло характер взаимодействия с музыкальным, иконографическим и архитектурно-скульптурным его оформлением. В процессе литургического действа молитвенное слово пробуждало у верующего широкий спектр

\footnotetext{
8 Там же. С. 223.

9 Консон Г.Р. Психология трагического: Проблемы конфликтологии (на материале западноевропейского искусства). М.: Нобель-Пресс; Edinburgh: Lennex Corporation, 2013. C. 152.

10 Бонавентура. О возвращении наук к теологии // Антология средневековой мысли: В 2-х тт. Т. 2. СПб., 2002. С. 129.
}

эмоций, направляемых к божественному светоносному образу. Лексика Средневековья благодаря символическому характеру обладала семантической многозначностью, активизировала эмоциональную и образно-смысловую память, предполагала синестезийность как основу восприятия. В частности, термин «lux» означал «свет», «ясность», «сияние», сравнивался в сияющей ризой, в которую облачается Господь: «Господи, Боже ты мой! Ты дивно велик, Ты облечен славою и величием; Ты одеваешься славою, как ризою, простираешь небеса, как шатер» (Пс. 103).

Феномен света, как утверждают психоаналитики и религиозные мистики, является онтологическим коррелятом космического совершенства и целостности, объединяющей сферу бытия и сознания. В средневековых религиозных текстах появляется игра смыслов на основе близости слов «свет-сияние» и «святость»: святость может воссиять, набраться некой духоносной силы, энергии и проявиться во внешней форме - световой и цветовой, захватывая не только глаз, но и сердце, душу человека, соотнося их с неким высшим началом, с божественными энергиями. Для сирийского почитателя греческой культуры и ее традиций Феофила Антиохийского Солнце - это образ Бога, человек же подобен Луне, которая сама не светит, но проявляется на небосклоне, отражая свет Солнца. Феофил выстраивает систему метафорических уподоблений космологического характера: пророку соответствуют наиболее яркие звезды, праведникам - менее яркие ${ }^{11}$.

Показательно, что в оптической физике механизм возрастания длин световых волн по цветовой шкале показывает рост интенсивности выделяемой энергии испускаемого света в зависимости от длины волны, где нижний уровень занимает фиолетовый цвет (460 нанометра - нм, «фиолетовые миры» неслучайно у А. Блока были связаны с демоническим началом), зеленый, заметное повышение энергетических показателей наблюдается у желтого (580 нм), красного цветов (640 нм). Наиболее интенсивные ощущения вызывает пурпурный цвет (700 нм). Инфракрасный цвет плохо воспринимается человеком из-за чрезмерно большого количества выделяемого им тепла. Цвета «верхней воспринимаемой глазом цветовой шкалы (желтый,

11 История эстетики. Памятники мировой эстетической мысли : В 5-и тт. Т. 1 : Античность, Средние века, Возрождение. М.: Изд-во Академии Художеств СССР, 1962. С. 74. 


\section{Многообразие религиозного опыта}

красный, пурпурный) активно используются в религиозной практике (иконография, утварь святилищ, одежды священников).

Однако в христианстве происходит смысловое переключение понятия святости, столь важного в языческой культуре и имеющего мистикоприродную сущность (святые воды, святые рощи), представления о светоносности отрываются от чисто эмпирических ощущений. Святость Духа, веры, человека, литургии, храма основывается на иных принципах, для которых внешние атрибуты являются вспомогательными. Богословие готово обрести духовный, пневматический (греч., пневма - «дух») модус и перейти на интуитивный, сверхметафорический язык. Происходит переориентация сознания с природы на человека, с видимого, материального - на незримое, абстрактное. В результате понятие святости все более актуализирует смыслы, связанные со сферой этики (праведность, непорочность, чистота). Святость становится энергетической характеристикой, обусловленной светоизлучением богоуподобившейся души праведника ${ }^{12}$.

Направленность искусства эпохи Средневековья на осмысление трансцендентных основ творчества демонстрирует, что эстетическое восприятие не является «чистым», оно неразрывно процессом этического и онтологического осмысления художественного образа. Процесс восприятия искусства основывался на том, чтобы результатом его было преображение разума Божественным светом, при котором открывалось видение единства сотворенного Богом бытия. «Если мы все видим в Боге и все с ним соотносим, - говорили апологеты, то тогда и в обычных предметах мы читаем высшее выражение смысла» ${ }^{13}$.

В концепции соборных искусств мы наблюдаем неразделение этического и онтологического, своеобразный неосинкрезис ${ }^{14}$. Напомним, что идея синтеза искусств имела сложную судьбу на протяжении всего Средневековья и, по сути, она является достижением уже зрелого этапа средневековой

12 Топоров В.Н. Святость и святые в русской духовной культуре: В 2-х тт. Т. 1 : Первый век христианства на Руси. М.: Шк. «Языки рус. культуры», 1995. С. 490.

13 Цит. по: Хёйзинга Й. Осень Средневековья. М.: Прогресс, 1995. С. 222.

14 Зайцева М.Л. Синестезийность как системное свойство художественного сознания: Дис. ... докт. искусствоведения. M., 2014. C. 117. культуры. Особое место в патристике уделялось исследованиям особенностей воздействия синтеза сакральных видов искусств в богослужении, обнаружению тех «терний», которые способны заглушить Божественное Слово, снизить эффект его воздействие на человека. Основная полемика в средневековой патристике разворачивалась именно по поводу умножения сенсорности, чувственного впечатления в процессе соединения разных видов искусств.

Единый, а значит достигший полноты и совершенства для воплощения религиозных догматов архитектурно-скульптурный стиль появляется в Европе лишь к XI веку. Гораздо раньше начинается формирование единых точек зрения на использование в церковной службе пения. Следуя обычаям Восточной Церкви, Амвросий Медиоланский вводит практику «утешать и наставлять с помощью пения» ${ }^{15}$ формируя традицию церковного пения, впоследствии названную «амвросианской». Ученик Амвросия Аврелий Августин видит опасность нововведения в сильном чувственном эффекте пропетого слова, когда чувство опережает разум. Волновать должно, по мнению Августина, не пение, а то, о чем поется, «так и колеблюсь я, - и наслаждение опасно, и спасительное влияние пения доказано опытом». Склоняясь к тому, чтобы не произносить бесповоротного суждения, Аврелий определяет адресата интонированного слова: «пусть душа слабая, упиваясь звуками, воспрянет, исполняясь благочестия. Когда же со мной случается, что меня больше трогает пение, чем то, о чем поется, я каюсь в прегрешении; я заслужил наказания и тогда предпочел бы вовсе не слышать пения» ${ }^{16}$.

Аврелий Августин, изучая особенности объединения слова с музыкальной интонацией, с одной стороны, отмечает усиление характера воздействия художественных языков в процессе их синтеза, с другой - подвергает критике увеличение чувственных впечатлений, особенно удовольствия как чувства, направляющего нас на путь греха. Такое мнение характерно для Макарий Египетский, Иоанн Лествичник, Исаак Сирин, Симеон Новый Богослов. Именно в среде византийского монашества, выдвинувшей вслед за ранними христианами идеал нестяжательной жизни, отказ от

15 Августин А. Исповедь // Аврелий Августин. Исповедь. П. Абеляр. История моих бедствий. М.: Республика, 1992. C. 119.

16 Там же. С. 151. 
чувственных наслаждений в пользу духовных, постулируются основные темы эстетики аскетизма, имеющей, как правило, эстетический объект во внутреннем мире самого эстетического субъекта.

Анализируя многоаспектность чувственного восприятия и его роль в процессе мышления, Августин создает методологическую основу для будущих комплексных исследований. По его мнению, мир есть совокупность разнообразных предметов, созданных Творцом с целью придания красоты и совершенства творению. Познание человеком мира предполагает, таким образом, не только определение сути отдельных вещей и явлений, но и рассмотрение их взаимосвязей. Представление о хаотичности, беспорядочности, безобразности и безобразности мира ошибочно. Его причиной является заблуждение, рассуждает Августин, возникающее от ограниченности человеческого сознания, не способного узреть взаимосвязь и гармоничность явлений мира, их симфоническое, многоголосное слияние в совершенной божественной музыке. Угол дома не даст представлений о красоте всего здания, камешек - о совершенстве мозаики, слово и звук - о красоте стиха и музыкального произведения ${ }^{17}$.

Аврелий Августин разрабатывает новые подходы к пониманию процесса восприятия искусства. Выделяя как основные две функции искусства знаково-символическую и эмоционально-эстетическую, направленную на прямое воздействие, он разрабатывает теорию знака и значения, пользы и вреда чувственного восприятия, то приближающих, то удаляющих от постижения истины в зависимости от активности дисциплинирующего контроля разума.

Усиление чувственного воздействия полемически воспринималось отцами Церкви. Во многих византийских гимнах повторяется призыв духовно «встать», сделать «усилие сердца», принять строгую и напряженную позу души, выпрямиться в присутствии святыни ${ }^{18}$. Среди них есть один, само название которого выражает запрет сидеть при его исполнении: «гимнос акафистос» (букв.: «гимн, при слушании которого нельзя сидеть», в старославянском переводе - «неседален»). Любопытство и наслаждение, спровоцированное неправильным применением художественных элементов в рамках сакрального искусства, мешает молитвенному со-

\footnotetext{
17 Там же. С. 140.

18 Аверинцев С.С. Поэтика ранневизантийской литературы. M.: Coda, 1997. C. 81.
}

средоточению и закрывает путь вхождения Божественной истины в глубину человеческого сердца. Бернард Клерворский, рассматривая обилие причудливых скульптур на готических соборах, критикует своего современника, идеолога готического стиля, аббата Сугерия: «со всех сторон такое разнообразие и богатство форм, что забавнее изучать целый день этот пестрый мир скульптур, чем думать о заповедях Божиих» ${ }^{19}$.

В основе эстетического восприятия средневекового искусства всегда находится умозрительный образ, обращающийся к культуре духа и высокой практике очищения от ложных образов. Восхождение от чувственного восприятия к морали и трансцендентному образу мыслилось как иерархия духовных отражений. Для постижения истинной красоты бытия необходимо «всегда носить в себе божественные образы, чистые, не смешанные с дольними и обманчивыми впечатлениями, быть и непрестанно делаться как бы неомраченным зерцалом Бога» - писал Григорий Назианзин $(\text { Богослов })^{20}$. Григорий Палама в трактате «Триады в защиту священно-безмолвствующих» отмечает, что Бог «являет Себя очистившемуся уму как бы в зеркале, сам по себе оставаясь невидимым, потому что таково свойство зеркального образа: он очевиден и его не видать» ${ }^{21}$.

Процесс эстетического восприятия направлен на духовное спасение, на раскрытие всей сферы восприятия и познания человека в полноте любви через сострадание. Все элементы сакрального искусства выступали в роли импульсов для сенсорных ощущений и возникающего эмоционального резонанса. «Ведь как Бог везде есть весь, так и душа - во всех членах тела... соотносится со всеми телесными чувствами», - трактовал этот процесс Гуго Сен-Викторский ${ }^{22}$.

\footnotetext{
19 Кляйн Б. Зарождение и развитие готической архитектуры во Франции и соседних странах // Готика. Архитектура. Скульптура. Живопись / Под ред. Рольфа Томана. Konemann, 1998. C. 68 .

20 Григорий Богослов. О своей жизни // Восточные отцы IV века / Г.В. Флоровский. М. : Паломник, 1992. С. 104.

21 Григорий Палама. О священно-безмолствующих // Добротолюбие (в русск. пер.). Изд-е второе, доп. Т. 5. Киев: PSYLIB, 2006. (psylib.org.ua/books/dobrl05/).

22 Гуго Сен-Викторский. О созерцании и его видах // Антология средневековой мысли. Теология и философия европейского Средневековья: В 2-х тт. Т. 1. СПб.: РХГИ, 2001. C. 348 .
} 


\section{Многообразие религиозного опыта}

Для понимания синестезийных основ религиозного и художественного мышления весьма продуктивным оказывается практика видения «глазами сердца», особенно распространенная в монашеской среде, приемы эмпатического вживания в зримый Божественный образ, запечатленный в иконе. Напомним, что в Ветхом завете слово «сердце» упоминается наиболее часто: 851 раз, становясь важнейшим символом библейских представлений о человеке. Именно сердце в святоотеческой литературе понимается как некий потаенный внутренний центр (трон, «седалище ума»), к которому должно быть направлено сосредоточенное усилие аскета. Так, отвечая на вопрос о месте обитания ума священно-безмолствующих, Григорий Палама отмечал: «одни водворяют его в мозгу, как в некоем акрополе (кремле); другие дают ему седалище в сердцевине сердца» ${ }^{23}$. Византийский богослов и философ соглашается с мнением последних, упоминая высказывания Макария Великого о необходимости содержания сердца в чистоте, ибо «сердце правит всем органом, и, когда благодать займет все отделения сердца, господствует над всеми помыслами и членами, ибо там ум и все помыслы душевные» ${ }^{24}$. Как отмечал А.Ф. Лосев, если платоник не разделяет тело и дух, не различает физиологические моменты восхождения к божественной истине, то исихиасты воспринимают образ своего Бога сердцем и дыханием, направляют ум в грудь и сердце ${ }^{25}$.

Сердце в святоотеческих текстах предстает как орган, способный дрожать от веселья и ужаca, которое может стать мягким как воск. Семиотика христианских представлений о телесности включает в себя физиологическую конкретность, придающую интимную глубину воспринимаемым истинам, наделяя их личностным отношением: качественное состояние сердца как органа сопереживания делает человека «сердечным» или «сердитым», наполняет образы божественной любви сердечной (и чревной) теплотой. Послушайте, что говорит Господь: «воскроплю на вы воду чисту и очиститеся от всех нечистот ваших: и очищу вас, и дам вам сердце ново, и дух нов дам вам, и отъиму

23 Григорий Палама. О священно-безмолствующих // Добротолюбие (в русск. пер.). Изд-е второе, доп. Т. 5. Киев: PSYLIB, 2006. (psylib.org.ua/books/dobrl05/).

24 Там же.

25 Лосев А.Ф. История античной эстетики: Последние века (III-VI века). М.: Искусство, 1988. С. 259. сердце каменное от плоти вашея; и дам вам сердце плотяно, и Дух мой дам в вас» (Иез. 36:25-26).

Красота библейских истин познается при помощи синестезийности сознания: не случайно представления об остроте и прозорливости ума, которые помогают проникнуть в тайнозамкнутые смыслы, связаны с представлением о пронзенности, уязвлении, ранении, прободании, проникновении. Болевые ощущения выполняли важные эстетические функции. Это телесность родовых мук, мучений шествия на Голгофу, крестного распятия. Приобщиться к вере через искусство означало соощутить телесные и душевные муки Христа, изображаемые на иконах, раскрываемые в литургическом слове. Именно опыт телесных ощущений помогает сердцу человека стать из жестокого, каменного - мягким, сокрушенным.

Анализируя в труде «Стигмата и смысл памяти» семиотические функции ран, изображаемых в сюжетах страстных циклов, Ж. Бене отмечает, что «видение глазами сердца» предполагало активную связь тактильного, визуальных и интероцептивных (органических, связанных с состоянием организма) ощущений ${ }^{26}$. Это свидетельствует о несомненном присутствии синестезии в средневековом мышлении и восприятии. Видение «очами сердца, очищенными состраданием и любовью, и обретшими способность созерцать божественную красоту» становится основой художественно-эстетического восприятия. Синестезия становится основой процесса символизации языка, объединяющего божественные и человеческие миры через яркие образы, обращенные ко всему спектру ощущений.

Синестезийность символического мышления способствует формированию семантического пространства, в котором значения взаимосвязаны и устремлены в итоге к единому абсолютному трансцендентному смыслу. В одном из гимнов Ефрем Сирин уподобляет свой разверстый для принятия Евхаристии рот - раскрытому для впускания божественных истин уму:

«Господи, написано в Книге Твоей:

«открой уста твои, Я наполню их».

Вот, Господи, уста раба Твоего

и ум его - открыты Тебе» ${ }^{27}$.

26 Bennet J. Stigmata and Sense Memory: St. Francis and the Affective Image // Art History. February 2001. Vol. 24. № 1. P. 1-17.

27 Цит. по: Аверинцев С.С. Риторика и истоки европейской литературной традиции. М. : Языки русской культуры, 1996. C. 80 . 
Логика символического мышления объединяет Божественное Слово и человеческую «утробу», «сердце». Вместе с тем и телесность становится священным письмом: «Вы показываете, что вы письмо Христово, - обращается апостол Павел к ученикам, - через служение наше написанное не чернилами, но Духом Бога живого, не на скрижалях каменных, но на плотяных скрижалях сердца» (2 Кор. 3:2-3). Показательно, что в христианстве акцентируется момент личностного бытия, конкретики его существования. Настоящий текст - сам Христос, вероятно, он сам ничего не писал, его общение с людьми строилось на устном слове и конкретных действиях, описанных позднее его учениками. Текст священных книг расширяется и обогащается «живым» текстом личностного бытия, о котором говорил апостол Павел, в котором истина обретает черты интимности, доверительности, эмоционально-чувственной полноты.

Это свойство библейского мировоззрения (устранение границ между материальным и духовным, мирским и теологическим) позволяет снять границы между телесным и бестелесным в таинствах. Именно в таинстве знак из аллегории (в которой также сопрягаются видимое и невидимая вещественности) трансформируется в символ, в котором не дистанции между предметом и смыслом, а есть их непостижимое тождество ${ }^{28}$.

Синестезийность ощущений репрезентируется благодаря памяти. Психология памяти, основы которой были впервые изложены Аристотелем в трактате «0 душе», в Средневековье изучалась Аврелием Августином, Авиценной и Аверроэсом. В Средневековье проблема памяти решается сквозь призму идеи о спасительном воспоминании, воссоздающего целостный образ во всей его чувственной полноте. Для Климента Александрийского эта работа мысли, направленная на воссоединение с Богом, поясняется через яркий зримый образ: «Луговые цветы растут как им вздумается, и плодовые деревья в саду не располагаются отдельными плантациями, согласно их виду, как если бы кто-то составил научную коллекцию: луга, геликоны, пасеки, покровы и т. д. Точно так же и мы, поскольку записываем предметы по мере их припоминания и не следуем какому-либо определенному порядку или последовательности изложения, но, например, намеренно их смешиваем, наши заметки по форме

28 Аверинцев С.С. Поэтика ранневизантийской литературы. М.: Coda, 1997. С. 79. столь же разнообразны, как и луг. Заметки эти и в некотором смысле подобны первой искре, зажигающей огонь, поскольку готовый к восприятию гнозиса, если ему случится прочесть их, будет вознагражден за потраченные усилия, и исследование пойдет ему на пользу» («Строматы») ${ }^{29}$.

Аврелий Августин изучает механизм появления в сознании человека мыслей, пробужденных ощущениями и чувствами, но к ним не сводимым. «Откуда они вошли в меня? Я обхожу все двери моей плоти и не нахожу, через какую они могли проникнуть. Глаза говорят: «если у них есть цвет, то возвестили о них мы». Уши говорят: «если они звучат, то о них доложили мы». Ноздри говорят: «если они пахнут, то они прошли через нас». Чувство вкуса говорит: «если у них нет вкуса, то нечего меня и спрашивать». Осязание говорит: «если они бестелесны, то нельзя их ощупать, а если нельзя ощупать, то я не могу о них доложить» ${ }^{30}$. Августин приходит к выводу, что возникновение мыслей не обязательно связано с непосредственным восприятием, оно может быть объяснено активизацией памяти в процессе мышления.

В основе памяти и ощущений, по мнению Августина, лежит желание. Оно регулирует способность памяти восстанавливать образы, воскрешать различные ощущения (любые цвета, звуки, вкусы, запах, формы), «при этом ничего отведывая и ничего не ощупывая, а только вспоминая» ${ }^{31}$. Показательно, что Августин определяет память как «желудок души»: помещение ощущений и переживаний в хранилище памяти изменяет их характер: «мои душевные состояния хранит та же память, только не в том виде, в каком их когда-то переживала душа, а в другом, совсем разном и соответствующем силе памяти» ${ }^{32}$. Будучи этим своеобразным «желудком души», наполняемом радостью и печалью - этой сладкой и горькой пищей, память изменяет вкус вверенных ей чувств: можно вспоминать бывшую печаль и печалиться, а иногда - радоваться, вспоминать страх, уже его не испытывая, припоминать былую страсть совсем бесстрастно. Чувства, как бы

\footnotetext{
29 Климент Александрийский. Строматы. СПб.: Изд-во Олега Абышко, 2003. С. 31.

30 Августин А. Исповедь // Аврелий Августин. Исповедь. П. Абеляр. История моих бедствий. М.: Республика, 1992. C. 136.

31 Там же. С. 89.

32 Там же. С. 137.
} 


\section{Многообразие религиозного опыта}

переправленные в желудок-память, лежат там, но «сохранить вкус не могут» ${ }^{33}$.

Активизация образно-смысловой памяти осуществлялась в религиозных текстах благодаря обращению к воспоминаниям, основанным на всем богатстве сенсорных ощущений. Однако именно символика света ставится определяющей в процессе восприятия, выстраивая логику раскрытия божественных смыслов как умозрительную по своей природе. Видение «очами сердца, очищенными состраданием и любовью, и обретшими способность созерцать божественную красоту» становится основой художественно-эстетического восприятия. Августин, Ареопагит, Бонавентура, Гуго Сен-Викторский, Фома Аквинский отмечали, что видимое глазами ни в коем случае не сравнимо с тем, что усматривает ум, «только разумное зрение не обманывает», телесное же зрение «принимает подобие за самые тела».

Отделить красоту от прелести, спасительное от гибельного, поставить поступки, мысли, чувства на должные места - это подвиг, приближающий к Богу. Это проявление преображенной сути человека, святости, которая красива в своей праведности, которая проявляется в феномене светового сияния: «можно сказать, что святой является человеком в большей мере, чем человек грешный, ибо, восстанавливая свое богоподобие, он достигает изначального смысла своего бытия, облекается в нетленную Красоту Царства Божия, в созидании которого он участвует своей жизнью. Красота есть святость в ее сиянии, причастие твари к Божественной красоте» (св. Дионисий Ареопагит). Средневековая религиозно-философской мысль объединяет понятия красоты - праведности - светоносности и придает им особую значимость не только в практике аскетизма, но и в художественной культуре.

Августин обстоятельно анализирует пагубное и спасительное действие органов чувств, которые, будучи направленными на любование прелестями мира и прежде всего самого себя, могут отвлечь человека от постижения истинной красоты, которая дается только, если внешний мир предстает как зеркало, пропускающее Божественный свет. При созерцании этой Божественной красоты все чувства обостряются и наполняют человека духовной любовью: «Поздно полюбил я Тебя, Красота, такая древняя и такая юная, поздно полюбил я Тебя... Со мной Ты был, с Тобой я не был... Ты позвал, крикнул и порвал глухоту мою. Ты сверкнул, засиял и прогнал слепоту мою; Ты разлил благоухание свое, я вдохнул и задыхаюсь без Тебя. Я отведал тебя и Тебя алчу и жажду. Ты коснулся меня, и я загорелся о мире Твоем» ${ }^{34}$.

Подводя итоги, отметим, что духовный синестикон есть реальность средневекового религиозного и художественного мышления. «Видение очами сердца», сохранение трезвенного состояния ума являются залогом негаснущего внутреннего зрения, позволяющего вернуть Божественному и художественному образу его полноту и смысл.

\section{Список литературы:}

1. Августин А. Исповедь // Аврелий Августин. Исповедь. П. Абеляр. История моих бедствий. М.: Республика, 1992.334 с.

2. Аверинцев С.С. Поэтика ранневизантийской литературы. M.: Coda, 1997. 343 c.

3. Аверинцев С.С. Риторика и истоки европейской литературной традиции. М.: Языки русской культуры, 1996.446 с.

4. Бонавентура. О возвращении наук к теологии // Антология средневековой мысли: В 2-х тт. Т. 2. СПб, 2002.635 с.

5. Евагрий Понтийский. 33 главы аналогий, или уподоблений. (simvol-veri.ru/.../evagriie-pontiieskiie.-evagriya-monaxanastavleniya-o-...).

6. ригорий Богослов. О своей жизни // Восточные отцы IV века / Г.В. Флоровский. М.: Паломник, 1992.240 с.

7. Григорий Палама. О священно-безмолствующих // Добротолюбие (в русском переводе). Изд-е второе, доп. Т. 5. Киев: PSYLIB, 2006. (psylib.org.ua/books/dobrl05/).

8. Гуго Сен-Викторский. О созерцании и его видах // Антология средневековой мысли. Теология и философия европейского Средневековья: В 2-х тт. Т. 1. СПб.: РХГИ, 2001. 539 с.

9. Гуревич П.С. Проблема целостности человека. М.: ИФ РАН, 2004. 178 с.

10. Зайцева М.Л. Синестезийность как системное свойство художественного сознания: Дис. ... доктора искусствоведения. М., 2014. 335 с.

11. История эстетики. Памятники мировой эстетической мысли: В 5-и тт. Т. 1: Античность, Средние века, Возрождение. М.: Изд-во Академии Художеств СССР, 1962. 684 с.

33 Там же. С. 138.

34 Августин А. Исповедь // Аврелий Августин. Исповедь. П. Абеляр. История моих бедствий. М.: Республика, 1992. C. 95 . 
12. К Климент Александрийский. Строматы. СПб.: Изд-во Олега Абышко, 2003. 544 с.

13. Кляйн Б. Зарождение и развитие готической архитектуры во Франции и соседних странах // Готика. Архитектура. Скульптура. Живопись / Под ред. Рольфа Томана. Konemann, 1998. С. 28-116.

14. Консон Г.Р. Психология трагического: Проблемы конфликтологии (на материале западноевропейского искусства). М.: Нобель-Пресс; Edinburgh: Lennex Corporation, 2013. 391 c.

15. Лосев А.Ф. История античной эстетики: Последние века (III-VI века). М.: Искусство, 1988. 447 c.

16. Макарий Великий. Иносказательное изъяснение видения, описанного Пророком Иезекиилем / Преподобный Макарий Великий. Беседы // Добротолюбие (в русском переводе). Изд-е второе, доп. Т. 14. Киев: PSYLIB, 2006. (psylib.org. ua/books/dobrl05/).

17. Медушевский В.В. Куда идем - куда заворачиваем? // Музыка изменяющейся России: Материалы всероссийской научно-практической конференции / Гл. ред. М.Л. Космовская; Отв. ред. В.А. Лаптева и Л.А. Ходыревская. Курск: Изд-во Курск. гос. ун-та, 2007. С. 19-26.

18. Платон. Собр. соч.: В 4-х тт. / Пер. с древнегреч.; Под общ. ред. А.Ф. Лосева, В.Ф. Асмуса, А.А. Тахо-Годи. Т. 2. М.: Мысль, 1993. $540 \mathrm{c}$.

19. Топоров В.Н. Святость и святые в русской духовной культуре: В 2-х тт. Т. 1: Первый век христианства на Руси. М.: Шк. «Языки рус. культуры», 1995. 874 с.

20. Хёйзинга Й. Осень Средневековья. М.: Прогресс, 1995. 414 с.

21. Bennet J. Stigmata and Sense Memory: St. Francis and the Affective Image // Art History. February 2001. Vol. 24. № 1. P. 1-17.

\section{References (transliteration):}

1. Avgustin A. Ispoved' // Avrelii Avgustin. Ispoved'. P. Abelyar. Istoriya moikh bedstvii. M.: Respublika, 1992. 334 s.

2. Averintsev S.S. Poetika rannevizantiiskoi literatury. M.: Coda, 1997. 343 s.

3. Averintsev S.S. Ritorika i istoki evropeiskoi literaturnoi traditsii. M.: Yazyki russkoi kul'tury, 1996. $446 \mathrm{~s}$.

4. Bonaventura. O vozvrashchenii nauk k teologii // Antologiya srednevekovoi mysli: V 2-kh tt. T. 2. SPb., 2002. $635 \mathrm{s.}$

5. Evagrii Pontiiskii. 33 glavy analogii, ili upodoblenii. (simvol-veri.ru/.../evagriie-pontiieskiie.-evagriya-monaxanastavleniya-o-...).

6. Grigorii Bogoslov. O svoei zhizni // Vostochnye ottsy IV veka / G.V. Florovskii. M.: Palomnik, 1992. 240 s.

7. Grigorii Palama. O svyashchenno-bezmolstvuyushchikh // Dobrotolyubie (v russkom perevode). Izd-e vtoroe, dop. T. 5. Kiev: PSYLIB, 2006. (psylib.org.ua/books/dobrl05/).

8. Gugo Sen-Viktorskii. O sozertsanii i ego vidakh // Antologiya srednevekovoi mysli. Teologiya i filosofiya evropeiskogo Srednevekov'ya: V 2-kh tt. T. 1. SPb.: RKhGI, 2001. 539 s.

9. Gurevich P.S. Problema tselostnosti cheloveka. M.: IF RAN, 2004. $178 \mathrm{~s}$.

10. Zaitseva M.L. Sinesteziinost' kak sistemnoe svoistvo khudozhestvennogo soznaniya: Dis. ... doktora iskusstvovedeniya. M., 2014. $335 \mathrm{~s}$.

11. Istoriya estetiki. Pamyatniki mirovoi esteticheskoi mysli: V 5-i tt. T. 1: Antichnost', Srednie veka, Vozrozhdenie. M.: Izd-vo Akademii Khudozhestv SSSR, 1962. 684 s.

12. Kliment Aleksandriiskii. Stromaty. SPb.: Izd-vo Olega Abyshko, 2003. 544 s.

13. Klyain B. Zarozhdenie i razvitie goticheskoi arkhitektury vo Frantsii i sosednikh stranakh // Gotika. Arkhitektura. Skul'ptura. Zhivopis' / Pod red. Rol'fa Tomana. Konemann, 1998. S. 28-116.

14. Konson G.R. Psikhologiya tragicheskogo: Problemy konfliktologii (na materiale zapadnoevropeiskogo iskusstva). M.: Nobel'Press; Edinburgh: Lennex Corporation, 2013.391 s.

15. Losev A.F. Istoriya antichnoi estetiki: Poslednie veka (III-VI veka). M.: Iskusstvo, 1988. 447 s.

16. Makarii Velikii. Inoskazatel'noe iz"yasnenie videniya, opisannogo Prorokom Iezekiilem / Prepodobnyi Makarii Velikii. Besedy // Dobrotolyubie (v russkom perevode). Izd-e vtoroe, dop. T. 14. Kiev: PSYLIB, 2006. (psylib.org.ua/books/dobrl05/).

17. Medushevskii V.V. Kuda idem - kuda zavorachivaem? // Muzyka izmenyayushcheisya Rossii: Materialy vserossiiskoi nauchnoprakticheskoi konferentsii / Gl. red. M.L. Kosmovskaya; Otv. red. V.A. Lapteva i L.A. Khodyrevskaya. Kursk : Izd-vo Kursk. gos. un-ta, 2007. S. 19-26.

18. Platon. Sobranie sochinenii: V 4-kh tt. / Per. s drevnegrech.; Pod obshch. red. A.F. Loseva, V.F. Asmusa, A.A. Takho-Godi. T. 2. M.: Mysl', 1993. $540 \mathrm{~s}$.

19. Toporov V.N. Svyatost' i svyatye v russkoi dukhovnoi kul'ture: V 2-kh tt. T. 1: Pervyi vek khristianstva na Rusi. M.: Shk. «Yazyki rus. kul'tury», $1995.874 \mathrm{~s}$.

20. Kheizinga I. Osen' Srednevekov'ya. M.: Progress, 1995. 414 s.

21. Bennet J. Stigmata and Sense Memory: St. Francis and the Affective Image // Art History. February 2001. Vol. 24. № 1. P. 1-17. 